DOI: https://doi.org/10.34069/AI/2021.43.07.3

How to Cite:

Kushnir, Y., \& Hutsuliak, M. (2021). The Human Concept in Russian Neomodernist Prose of the 21st Century. Amazonia Investiga, 10(43), 32-40. https://doi.org/10.34069/AI/2021.43.07.3

\title{
The person of the criminal that committed a criminal offence in the field of inviolability of State Border of Ukraine
}

\section{Особа злочинця, який вчинив кримінальне правопорушення у сфері недоторканності державного кордону України}

Received: May 29, 2021

Accepted: July 8, 2021

\author{
Written by: \\ Yaroslav Kushnir ${ }^{8}$ \\ https://orcid.org/0000-0002-8519-5331 \\ Mykola Hutsuliak ${ }^{9}$ \\ https://orcid.org/0000-0002-6646-6765
}

\begin{abstract}
The purpose of our study is to form a typical criminological profile of a person who has committed a criminal offense in the field of protection of the State Border of Ukraine. Based on the detailed study of the sentences issued by the national courts of Ukraine during 2015-2020 concerning such persons, a typical criminological profile of the person was formulated. Thus, the typical criminological profile is a male $(95.7 \%)$, a citizen of Ukraine $(89 \%)$, Ukrainian by nationality $(82.6 \%)$, married or living in common-law marriage $(69.6 \%)$, with low income $(67.4 \%)$. Not previously convicted (87\%), committed the crime to obtain additional funds $(86.9 \%)$, admits guilt in full, repents, contributes to the disclosure of the crime $(84.8 \%)$. Specialized research methods are applied. The comparative method is used to compare the characteristics of the offender, who violated the order of entry into and exit from the temporarily occupied territory of Ukraine and other crimes that encroached on border security. The logical-legal method is used to form logical, systematic, and consistent conclusions. The study is based on research of 38 sentences imposed on 46 people. The data obtained allowed us to interpret them as a characteristic of the offender.
\end{abstract}

Keywords: the person of a criminal, criminal offense in the field of inviolability of state borders, typical criminological profile of a person, violation of the procedure of entry and

\begin{abstract}
Анотація
Метою нашого дослідження $є$ формування типового кримінологічного портрета особи, яка вчинила кримінальне правопорушення у сфері охорони державного кордону України. На основі детального вивчення вироків, що винесені національними судами України упродовж 2015-2020 років відносно таких осіб, сформульовано типовий кримінологічний портрет особи. Таким чином типовим кримінологічним портретом $€$ - особа чоловічої статі $(95,7 \%)$, громадянин України (89\%), за національністю українець $(82,6 \%)$, одружений або проживає у цивільному шлюбі $(69,6 \%), 3$ низьким достатком $(67,4 \%)$. Раніше не судимий $(87 \%)$, злочин вчинив 3 метою отримання додаткових коштів $(86,9 \%)$, вину визнає повністю, розкаюється, сприяє розкриттю злочину $(84,8 \%)$. У статті використовувались спеціальні методи дослідження. Порівняльний метод - для порівняння характеристик правопорушника, який порушив порядок в 'їзду та виїзду з тимчасово окупованої території України та інших злочинів, що посягають на безпеку кордону. Логіко-правовий метод був використаний для формування логічних, систематичних та послідовних висновків. Дослідження базувалося на вивченні 38 вироків, винесених відносно 46 осіб. Отримані дані дали можливість інтерпретувати ї як характеристику злочинця
\end{abstract}

\footnotetext{
${ }^{8}$ Senior instructor of the administrative activity Department of the National Academy of the State Border Guard Service of Ukraine named after Bohdan Khmelnytskyi, Khmelnytskyi, Ukraine.

${ }^{9}$ Leading specialist of the Ciscarpathian Faculty of the National Academy of Internal Affairs, PhD in Law, Associate Professor,
} Ivano-Frankivsk, Ukraine. 


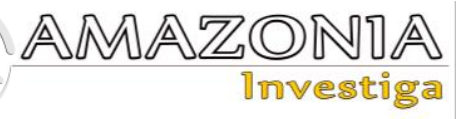

departure, temporarily occupied territory, state border.

Ключові слова: особа злочинця, кримінальне правопорушення у сфері недоторканності державного кордону, типовий кримінологічний профіль особи, порушення порядку в'їзду та виїзду, тимчасово окупована територія; державний кордон.

\section{Introduction}

The basic law defines that Ukraine is a sovereign and independent, democratic, social, legal state. According to the Constitution of Ukraine, the Declaration of State Sovereignty of Ukraine and the Act of Independence of Ukraine, our country steadfastly pursues a policy of peace, maintains strengthening of the security of the peoples of Ukraine based on the principles of inviolability of state borders, which are the reflection of the territorial integrity, political and economic independence and sovereignty and unity of Ukraine. The state border of Ukraine is inviolable. Any violations of it are decisively stopped (Law No 1777-XII, 1992).

The military conflict in eastern Ukraine led to the temporary occupation of part of the integral territory (the Autonomous Republic of Crimea, part of the territory of Donetsk and Luhansk regions) and the simultaneous violation of the State Border of Ukraine.

This generated a need for the criminalization of such a phenomenon as entry and departure from the temporarily occupied territory of Ukraine. Art. 332-1 has been added to the Criminal Code of Ukraine (hereinafter - the CC of Ukraine) (Law No 2341-III, 2001) according to the Law of Ukraine "On ensuring of the rights and freedoms of citizens and the legal regime at the temporarily occupied territory of Ukraine" from April 15, (Law No 1207-VII, 2014), which provides responsibility for violation of the procedure of entry and departure from the temporarily occupied territory of Ukraine as another one of the criminal offenses in the area of incompatibility of the State Border of Ukraine. In addition to protecting of the economic interests of the state, criminal liability for violating of the procedure of entry and departure from the temporarily occupied territory of Ukraine is designed to protect Ukraine from possible terrorist threats that have been relevant since military aggression (Liashuk \& Vychavka, 2020).

In the modern world practice, there are examples of occupation of foreign territories (annexation) (Abkhazia, Palestine, South Ossetia,
Transnistria, Somaliland, etc.), among the variety of political and legal ways to resolve such conflicts, criminal measures occupy a leading place. These include the criminalization of acts related to the violation of the procedure of entry and departure from the temporarily occupied territory of Ukraine as one of the ways to ensure the inviolability of state border.

As noted (Krishnendra, 2020), states use different border methods that are relevant to their relationship. When relations are friendly, borders and border practices can hardly exist, and where there is hostility, borders are very strictly guarded and border methods are strict. However, in both scenarios, the impact of two different areas of sovereignty affects the lives of people living in the border area. For example, Pakistan's border policy along the border between Pakistan and Afghanistan after 2014 is a strategy to strengthen the borders and is to use not only physical force but also weapons to defeat. India and Egypt have in fact recognized the killing of unarmed people illegally crossing the border, recognizing them as a threat to their national security, even though such people do not even attack border guards (Oztig, 2020). More effective border security can confirm the state sovereignty (Gundhus \& Jansen, 2020).

The effectiveness of protection of the national interests of Ukraine through bringing the perpetrators to criminal responsibility for violation of the procedure of entry and departure from the temporarily occupied territory of Ukraine should be achieved by a set of criminological measures. It is also important to work out an effective prevention system. The study of the person of a criminal is considered by criminologists to be an important component of the theory of prevention of the criminal. Criminology knows various theories related to the study of the person of a criminal (anthropological - Lombroso, which later failed to withstand criticism, psychological - Freud, sociological - Kettle, conflict theory - Marx, theory of social anomie - Durkheim, the theory of cultural conflict, stigmatization, theory of subcultures, a combination of social and 
biological in the person of a criminal). All above mentioned theories are directly related to the study of the characteristics of the criminal.

The purpose of our research is formation of the typical criminological profile of a person, who committed a criminal offense in the field of protection of the State Border of Ukraine, namely, violation of the order of entry into and exit from the temporarily occupied territory of Ukraine.

To achieve the goal of the study we solved the following research tasks:

1. What are the features of criminals convicted of these crimes?

2. Is it possible to work out a typical profile of such criminals on the basis of the obtained characteristics?

3. An attempt has also been made to identify patterns of characteristics of criminals that are common and can be used to assess risks.

\section{Review of literature or research background}

The results of research conducted in 1980-1990 by Soviet criminologists prove that a criminogenic personality is classified into types according to the degree of stability of personal deformation (Argunova, Yu., Dolgova A., Vaniushkin, S., Vashchenko, Yu., Grishko, A., et al., 2001). Based on this, the following classification has been formed: random criminals; criminogenic personality; sequential criminogenic subtype; situational-criminogenic subtype; situational subtype. In addition, we can distinguish the types of criminals by the nature of criminal motivation: violent type; mercenary; careless criminals; persons who commit crimes in order to obtain a minimum maintenance (Argunova, Yu., Dolgova A., Vaniushkin, S., Vashchenko, Yu., Grishko, A., et all, 2001).

The formation of the criminological profile of a criminal in foreign literature is called "criminal profiling", in addition, it is "a method of determining the basic personal and behavioural characteristics of a person based on the analysis of his crime" (Douglas et al., 1986). It is obvious that such an attempt to study the person of the criminal is necessary both for the investigation authorities and for the implementation of prevention measures. Despite of existing criticisms of the effectiveness of criminal profiling (Bartol, 1996) and the inability of existing crime theories to explain criminal behaviour (Weisburd et al., 2012), researchers continue to investigate this problem and the profiling of a person who committed a crime related to the inviolability of state border, which is not an exception.

The person of the criminal is of great scientific interest in modern criminological research; the criminal profile of the person committing human trafficking is being actively studied (Kuryliuk \& Khalymon, 2020). In the context of the military aggression against Ukraine, a typical profile of a traitor was formulated on the basis of court decisions (Polovnikov, Biletskyi, Tyshchuk, \& Overchenko, 2020). The study of conflict resolution in Abkhazia also attracts the attention of foreign scholars (Ditrych, 2008).

The problem of criminal liability for violation of the procedure of entry and departure from the temporarily occupied territory of Ukraine in domestic scientific works is also not ignored. However, the vast majority of them are related with the procedure and conditions of criminal prosecution (Nikitin, 2018; Ohniev, 2015; Antipov, 2015). Issues of substantiation of criminalization of this activity are discussed in the work (Danylevska, 2014). This author believes that establishing criminal liability for violation of investigated public relations, the legislative body has violated the principles of criminalization, which will not effectively allow using this rule and may lead to its exclusion from the CC of Ukraine (Danylevska, 2014). Practical lawyers also study the problems of liability for the researched criminal offense in the field of inviolability of the State Border of Ukraine through the seaports of the Autonomous Republic of Crimea (Kachmar, 2019). The work of (Ker-Lindsay, 2012) is of a considerable scientific interest. The author of the book analysed the efforts of the governments of Serbia, Georgia and Cyprus to prevent the international recognition of Kosovo, South Ossetia, Abkhazia and Northern Cyprus. Based on in-depth interviews with a number of leading politicians, it explains how each country has developed and implemented its strategies to counter annexation. There is also a thorough explanation of how the principle of territorial integrity of states tends to prevail over the right to self-determination. The author also investigated a number of ways in which countries that counteract separatism can prevent recognition by other states (Ker-Lindsay, 2012). The study of the characteristics of the criminal certainly contributes to the qualified investigation of crimes, and can also help in finding the offender (Ainsworth, 2001). Canter (2004) is convinced that the study of criminal behavior through profiling helps to predict and 


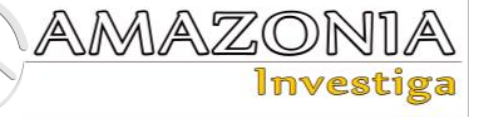

identify unknown offenders in order to facilitate their identification and detention (Canter, 2004). The last half century has shown that the scientific literature has been greatly enriched by empirical research aimed at studying the profiling of the criminal.

Despite this, the study of the person of the criminal who has committed such a criminal offense in the field of inviolability of the State Border of Ukraine as violated procedure of entry and departure from the temporarily occupied territory of Ukraine has not been carried out at present. Thus, our work is the first attempt to formulate a typical criminological profile of a person committing such a crime (profile of the offender) on the basis of the analysis of sentences imposed by national courts of Ukraine.

\section{Methodological Framework of the Research}

The methodological background of the study is based on general scientific methods of cognition, as well as the conceptual provisions of the sciences of the criminal law cycle (criminal law, criminology). Special research methods were utilized in the study. The author used the comparative method - to compare the characteristics of the offender who violated the order of entry into and exit from the temporarily occupied territory of Ukraine and other crimes that encroach on border security. The logicallegal method was used to form logical, systematic, and consistent conclusions.

This study conducted on the basis of a detailed study of sentences imposed by national courts of Ukraine during 2015-2020 against persons who committed a crime related to inviolability of the State Border of Ukraine.

The study covered 36 court verdicts adjudicated to 46 people. In our opinion, the studied sample is quite representative, given that during this time, no more than 100 guilty verdicts were adjudicated for committing the investigated criminal offense in Ukraine. Based on the analysis of the scientific literature on the researched issues, own experience, the authors prepared a questionnaire that included 12 questions divided into two blocks. It enables to gather of unique information about the identity of the offender.

The study was based on a investigation of 38 sentences imposed to 46 people, 15 of whom were convicted of committing this crime in a group. Thus, we relied only at official court sentences that came into force. Based on the study of sentences, a matrix of common characteristics has been formed. The obtained data made it possible to interpret them as a characteristic of the offender. The effectiveness of the use of cluster analysis in criminological research is confirmed by a number of scientific works (Grubesic and Murray 2001; Hindelang and Weis 1972; Kalichman 1988).

\section{Results and discussion}

Traditionally, domestic criminological science considers the personality of a criminal through a system of features, which together form a particular characteristic which allows forming a typical profile of such a person.

Based on the achievements of both domestic (Kuryliuk \& Khalymon, 2020; Khalymon, Polovnikov, and Volynets, 2020; Polovnikov, Biletskyi, Tyshchuk \& Overchenko, 2020;) and foreign scholars (Khoshnood \& Vafors Fritz, 2017; Eminov \& Antonyan, 2015; Içli, Sever \& Sever, 2015), interpreting their scientific developments in the field of formation of criminological characteristics of the criminal, we have developed a questionnaire including 12 typical characteristics inherent specifically to persons who commit criminal offenses related to encroachment on the inviolability of the state border of Ukraine.

This made it possible to lay out the attributes in the form of tables, presented below, based on which a matrix of general characteristics are formed.

The first group of characteristics consists of traditional socio-demographic characteristics, including gender, nationality, citizenship, marital status, educational level, occupation.

As a result of the study of sentences, it was found that the vast majority of convicts were male $(95,7 \%)$, such crimes were committed by only two women, which made $4,3 \%$ Table 1 . Conclusion that women are less likely to commit offenses than men, is not new, but has been repeatedly used in criminology from the beginning (Leuschner, 2020). To answer this difficult question, it is necessary to conduct thorough empirical research. 
Table 1.

Gender

\begin{tabular}{lll}
\hline & \multicolumn{1}{c}{$\boldsymbol{N}$} & \% \\
\hline Men & 44 & 95.7 \\
Women & 2 & 4.3 \\
\hline
\end{tabular}

Taking into account that the criminalization of such an act is connected military aggression against Ukraine, the nationality of the criminal is of some importance. It was ascertained that the vast majority of $82,6 \%$ of convicts were of
Ukrainian nationality, 13\% were Russians, 2,2\% were Kazakhs and Azerbaijanis. Despite their nationality, only $10,9 \%$ of the respondents had the citizenship of another country Table 2, Table 3.

Table 2.

Nationality

\begin{tabular}{lll}
\hline & \multicolumn{1}{c}{$\boldsymbol{N}$} & $\boldsymbol{\%}$ \\
\hline Russian & 6 & 13 \\
Ukrainian & 38 & 82,6 \\
Kazakh & 1 & 2.2 \\
Azerbaijanian & 1 & 2,2 \\
\hline
\end{tabular}

Table 3.

Citizenship

\begin{tabular}{llc}
\hline & $N$ & \% \\
\hline Russian Federation & 5 & 10,9 \\
Ukraine & 41 & 89,1 \\
\hline
\end{tabular}

An important characteristic for the formation of the profile of the offender is his marital status. Among the surveyed persons, $58,7 \%$ were in an official marriage, other $10,9 \%$ were in a so-called unregistered marriage (civil), 30,4\% of convicts were not married Table 4.

Table 4.

Family status

\begin{tabular}{lll}
\hline & $\boldsymbol{N}$ & $\boldsymbol{\%}$ \\
\hline Official marriage & 27 & 58,7 \\
Civil marriage & 5 & 10,9 \\
Not married & 14 & 30,4 \\
\hline
\end{tabular}

According to the educational level, convicted persons were characterized as follows: $2,2 \%$ had primary (elementary) education; the majority of $69,6 \%$ had secondary or secondary vocational education (working); 6,5\% of convicts had basic higher education and $21,7 \%$ had complete higher education Table 5.

Table 5.

Educational level

\begin{tabular}{lll}
\hline & $\boldsymbol{N}$ & $\mathbf{\%}$ \\
\hline $\begin{array}{l}\text { Primary education (less than 9 classes) } \\
\text { Secondary or secondary vocational education, (secondary }\end{array}$ & 1 & 2,2 \\
$\begin{array}{l}\text { school, lyceum, vocational technical school) } \\
\text { Basic higher education (college, technical college, medical } \\
\text { secondary school, junior specialist) }\end{array}$ & 32 & 69,6 \\
Complete higher education & 32 & 6,5 \\
\hline
\end{tabular}




\section{AMAZONIA \\ Tnvestiga}

By type of occupation, the studied persons were distributed as follows: $32,6 \%$ worked at working professions; $17,4 \%$ were engaged in legal

Table 6.

Occupation

\begin{tabular}{lll}
\hline & $\boldsymbol{N}$ & $\boldsymbol{\%}$ \\
\hline Workman & 15 & 32,6 \\
Employer & 8 & 17,4 \\
Serviceman (officer of the law) & 5 & 10,9 \\
Pensioner & 2 & 4,3 \\
Unemployed & 16 & 34,8 \\
\hline
\end{tabular}

The second group of features that we include in the characteristics of the profile of the offender who committed the researched criminal offenses in the sphere of inviolability of the state border are criminal law features such as previous conviction, crime scene, qualifying features, attitude to guilt, type and extent of imposed punishment, etc.

The formation of the person of the offender is associated, among other things, with the presence or absence of previous convictions. The sentences we studied showed that previously only $12 \%$ or six people were prosecuted. Four

Table 7.

Bringing to criminal liability in the past business activities; 10,9\% of convicts were servicemen; $4,3 \%$ were retirees and the most of surveyed were unemployed $-34,8 \%$ Table 6.

\begin{tabular}{lll}
\hline & $N$ & $\%$ \\
\hline Yes (conditional punishment) & 4 & 8.7 \\
Yes (imprisonment) & 2 & 4,3 \\
No & 4 & 87 \\
\hline
\end{tabular}

The place of the crime is of some interest, because there is a situation in Ukraine that this type of criminal offense can be committed in three parts of the sovereign territory. $45,7 \%$ of those surveyed committed crimes in Donetsk region, $41,3 \%$ in Luhansk region and only $13 \%$

Table 8.

The place of the crime people have previously been convicted for a similar crime and two have been convicted by courts in other countries. The remaining $87 \%$ were not previously prosecuted Table 7 . Comparing the results with similar data obtained by other researchers (Kuryliuk \& Khalymon, 2020), we conclude that those who violated the procedure of entry into the temporarily occupied territory of Ukraine and departure from it are less criminalized than those who are engaged at trafficking of migrants. After all, among them, those who were previously prosecuted were 18,47\% (Kuryliuk \& Khalymon, 2020).

\begin{tabular}{lll}
\hline & $N$ & $\%$ \\
\hline Donetsk region & 21 & 45,7 \\
Luhansk region & 19 & 41,3 \\
Line of delimitation of the temporarily occupied territory & 6 & 13 \\
with the ARC & 6 & \\
\hline
\end{tabular}

The vast majority $(56,5 \%)$ of convicted persons were prosecuted under the Part 1 of Art. 332-1 of the CC of Ukraine that is the crime was committed for the first time. 8,7\% of persons repeatedly committed a violation of the procedure of entry into committed this crime violating the procedure of entry into the temporarily occupied territory of Ukraine and departure from it on the line of delimitation of the temporarily occupied territory with the Autonomous Republic of Crimea (ARC) Table 8 . the temporarily occupied territory of Ukraine and departure from it, $32,6 \%$ committed this crime by prior conspiracy by a group of persons, and only one person, or $2,2 \%$ committed this crime using an official position Table 9. 
Table 9.

Qualifying features

\begin{tabular}{lll}
\hline & $N$ & $\%$ \\
\hline Part.1 & 26 & 56,5 \\
repeatedly & 4 & 8,7 \\
or by prior conspiracy by a group of persons & 15 & 32,6 \\
Or by official using an official position & 1 & 2,2 \\
\hline
\end{tabular}

Among the qualifying features, the motive for committing a crime occupies an important place, because it is the motivating cause of human behavior. The vast majority of $86,9 \%$ committed this crime for the purpose of making some profit, $73,9 \%$ transporting food to the temporarily occupied territory, another $13 \%$ carrying out passenger traffic outside the entry-exit check

Table 10.

The motive for the crime points. The others $13 \%$ committed such a crime in order to get into illegal armed groups operating in the temporarily occupied territories of Ukraine. It is importantly that there was not a single person among the convicts who indicated a desire to return to their relatives as a motive for committing this crime Table 10.

\begin{tabular}{lll}
\hline & $N$ & $\%$ \\
\hline With the aim to get into illegal armed groups & 6 & 13 \\
Return to relatives & 0 & 73,9 \\
Transported food & 34 & 13 \\
Profit-making & 6 & \\
\hline
\end{tabular}

The instrument of the crime in $67,4 \%$ of cases were vehicles, in $23,9 \%$ of cases were watercrafts (the delimitation line in Luhansk region strengths within the river Siverskyi Donets, so some

Table 11.

The instrument of the crime commitment people committed this crime with the help of watercrafts). $4,4 \%$ of people were detained with weapons Table 11.

\begin{tabular}{llll}
\hline & & $\boldsymbol{N}$ & $\boldsymbol{\%}$ \\
\hline Weapon & 4 & 4,4 \\
Vehicles & 31 & 67,4 \\
Watercrafts & 11 & 23,9 \\
\hline
\end{tabular}

An important feature that characterizes the trend of the offender is his attitude to guilt. It turned out that $84,8 \%$ of people pleaded guilty and entered into a plea agreement with the prosecutor, $4,3 \%$ pleaded guilty partially and 10,0\% did not admit their guilt Table 12 .

Table 12.

Attitude to guilt

\begin{tabular}{lll}
\hline & $\boldsymbol{N}$ & $\boldsymbol{\%}$ \\
\hline Plead guilty (plea agreement) & 39 & 84,8 \\
Do not admit guilt & 5 & 10,9 \\
Plead guilty partially & 2 & 4,3 \\
\hline
\end{tabular}

\section{Conclusions}

Summing up the results of the study we will try to answer our research tasks.
1. Thus, the analysis of the available features of the criminal gives us the opportunity to identify such features inherent to the majority of convicts for criminal offenses in 


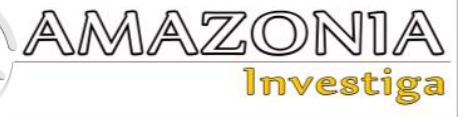

the field of protection of the state border of Ukraine, namely, violation of the procedure for entry into and exit from the temporarily occupied territory of Ukraine. Firstly, almost all $(95,7 \%)$ convicts were male. Secondly more than $(70 \%)$ convicts had either secondary or special secondary education. Thirdly, by occupation (either $32,6 \%$ ) were workers or $(34,8 \%)$ were unemployed, which in turn stimulated them to commit this crime. The fourth feature is that $(86,9 \%)$ convicts committed this crime for profitmaking.

2. The obtained results make it possible to formulate a typical criminological profile of a person who violated the procedure of entry into the temporarily occupied territory of Ukraine and departure from it. This is a male person $(95,7 \%)$, a citizen of Ukraine (89\%), a Ukrainian by nationality $(82,6 \%)$, married or living in a civil marriage $(69,6 \%)$, with low income $(67,4 \%)$. Not previously convicted $(87 \%)$, committed a crime in order to obtain additional funds $(86,9 \%)$, admits guilt in full, repents, promotes the disclosure of the crime $(84,8 \%)$. The nature of the criminal motivation is a selfish type, but a situational-criminogenic subtype, the crime was committed taking into account the difficult socio-economic conditions in which the region has been for the last five years.

3. With regard to the identification of legitimate characteristics of criminals, for use in risk assessment, it should be noted that the vast majority are locals living within the line of delimitation, using either personal transport or watercraft to commit a crime. Obviously, one of the main reasons that motivate citizens to commit the crime is the consequences of the armed aggression, which led to the destruction of the economy of the occupied territories. The war conflict caused enormous losses to the region, with total irreversible asset losses of more than \$ 84,6 billion in 2013 prices (Mykhnenko, 2020). Differences in prices for products and consumer goods stimulate the movement of such goods across the line of delimitation outside the entry-exit check points. The construction of a conditional "border" (line of delimitation) creates certain additional opportunities, because as noted (Bruns, Miggelbrink, J. and Müller, 2011), provide opportunities to carry out also profitable trading operations. This shows that the use of criminal law measures to prevent the commission of such crimes has little effect. After all, only $(15,2 \%)$ persons were sentenced to imprisonment, the rest were serving conditional sentences or a fine, i.e. they were slightly frightened and may continue their criminal activities in the future. However, there are opinions that given the resonance and political and economic conditionality of criminal liability for such actions, the punishment enshrined in the current version of the Criminal Code of Ukraine does not correspond to the degree of public danger of this crime (Nikitin, 2018).

In our opinion, solving this problem by criminal law alone is impossible, it is necessary to endorse at the state level programs for socio-economic development of regions bordering on the temporarily occupied territories, which will facilitate their reintegration and so on.

\section{References}

Ainsworth, P. (2001) Offender Profiling and Crime Analysis. New York: Routledge. by Willan Publishing 208 p.

Antipov, V. (2015) Qualification of violations of the procedure of entry into the temporarily occupied territory of Ukraine and departure from it. Juridical Ukraine, № 10-12, pp. 131-139.

Argunova, Yu., Dolgova A., Vaniushkin, S., Vashchenko, Yu., Grishko, A., et all (2001) Criminology. Manual for educational establishments. 2nd edition, with changes and amendments. Moscow: Infra-M-NORMA. 848 p.

Bartol, C. (1996). Police psychology: Then, now and beyond. Criminal Justice and Behavior, 23, 70-89.

Bruns, B., Miggelbrink, J. and Muller, K. (2011). "Smuggling and small-scale trade as part of informal economic practices: Empirical findings from the Eastern external EU border", International Journal of Sociology and Social Policy, 31(11/12), pp. 664680. https://doi.org/10.1108/01443331111177869

Canter, D. (2004). Offender profiling and Investigative Psychology. Journal of Investigative Psychology and Offender Profiling, 1, 1-15. DOI: http://dx.doi.org/10.1002/jip.7

Danylevska, Y. (2014) Violations of the procedure of entry into the temporarily occupied territory of Ukraine and departure from it: issues of grounded criminalization. Comparative-analytical law, № 8 , pp. $165-168$.

Ditrych, O. (2008) Identities, Interests and the Resolution of the Abkhaz Conflict. Caucasian Review of International Affairs, 2(3), 1-12

Douglas, J., Ressler, R., Burgess, A. W., \& Hartman, C. (1986). Criminal profiling from crime scene analysis. Behavioral Sciences \& the Law, 4, 401-421. 
Eminov, V. \& Antonyan, Y. (2015) Personality of a criminal and its formation. Actual problems of Russian law, 1(50), 107-112. Recovered from: https://cyberleninka.ru/article/n/lichnostprestupnika-i-ee-formirovanie/viewer

Gundhus, H., and Jansen, P. (2020) Pre-crime and Policing of migrants: Anticipatory Action meets management of concerns. Theoretical Criminology, 24(1) 90-109 DOI: 10.1177/1362480619873347 Grubesic, T.H. and Murray, A.T. (2001). Detecting Hot Spots Using Cluster Analysis and Gis. Fifth Annual International Crime Mapping Research Conference, Dallas, TX, 26.

Hindelang, M.J. and Weis, J.G. (1972) "Personality and Self-Reported Delinquency: An Application of Cluster Analysis." Criminology, 10(3), 268-294.

Içli, T. G., Sever, H., \& Sever, M. A. (2015). Survey Study on the Profile of Human Smugglers in Turkey. Advances in Applied Sociology, 5, 1-12. Kachmar, O. (2019) Price of the Crimean voyage: detention, arrest, and confiscation of vessels for illegal entry to occupied ports of Crimea. Recovered

from: https://vkp.ua/en/publication/price_of_the_c rimean_voyage_detention_arrest_and_confiscation _of_vessels_for_illegal_entry_to_occupied_ports_ of_crimea

Kalichman, Seth C. (1988). Empirically Derived Mmpi Profile Subgroups of Incarcerated Homicide Offenders. Journal of clinical psychology, 44(5), 733-738.

Ker-Lindsay, J. (2012) The Foreign Policy of Counter Secession Preventing the Recognition of Contested States. Oxford: Oxford University Press, $226 \mathrm{p}$.

Khalymon, S., Polovnikov, V., and Volynets, P. (2020). Socio-psychological Profile of a Person Who Confidentially Provides Assistance to the Operational Unit. Anuario de Psicología Jurídica, 30, 13- 20. https://doi.org/10.5093/apj2019a10

Khoshnood, A., \& Vafors Fritz, M. (2017). Offender Characteristics: A Study of 23 Violent Offenders in Sweden. Deviant Behavior, 38(2), 141- 153 .

Krishnendra M. (2020) Borders and Bordering Practices: A Case Study of Jaisalmer District on India-Pakistan Border. Journal of Borderlands Studies, 35(2), 183-194. https://doi.org/10.1080/08865655.2019.1646148

Kuryliuk, Y., \& Khalymon, S. (2020). Criminal profile of migrants' smuggler across the State Border of Ukraine. Amazonia Investiga, 9(27), 195-208.

https://doi.org/10.34069/AI/2020.27.03.21

Law No 1777-XII, 1992. On the State border of Ukraine: the law of Ukraine from the 4th of November 1991 № 1777-XII Base of legislation of the Supreme Council of Ukraine: Retrieved from https://zakon.rada.gov.ua/laws/show/177712\#Text

Law No 2341-III, 2001. Criminal Code of Ukraine. Base of legislation of the Supreme Council of Ukraine:

Retrieved

from https://zakon.rada.gov.ua/laws/show/234114\#Text

Law No 1207-VII, 2014. On ensuring of the rights and freedoms of citizens and the legal regime at the temporarily occupied territory of Ukraine. Base of legislation of the Supreme Council of Ukraine: Retrieved

from https://zakon.rada.gov.ua/laws/show/120718\#Text

Leuschner, F. (2020) Hintergründe und Deliktstrukturen von Straftaten durch Frauen. Forens Psychiatr Psychol Kriminol. (Backgrounds and tort structures of women by women. Forens Psychiatr Psychol Criminol) 14, 130-140

Liashuk, R., \& Vychavka, V. (2020) Experience of border guard units of the leading countries in countering terrorism and prospects for its implementation by the state border guard service of Ukraine. Juridical Tribune, 10(1), 102-115

Mykhnenko, V. (2020) Causes and Consequences of the War in Eastern Ukraine: An Economic Geography Perspective. Journal Europe-Asia Studies,

72(3), https://doi.org/10.1080/09668136.2019.168 4447

Nikitin, A. (2018) Criminal liability for the violation of the procedure of entry into the temporarily occupied territory of Ukraine and departure from it (dissertation of candidate of law). National Academy of Internal Affairs. Kyiv. 218 p. Retrieved

from http://elar.naiau.kiev.ua/jspui/handle/123456 789/6709

Ohniev, T. Ye. (2015) The person of the zlochintsya, the yaks of the vchyny, illegally transported the osibs through the state cordon of Ukraine. Science hour writing of the National Academy of the Prosecutor's Office of Ukraine, 4, 120-128.

Oztig, L.I. (2020): Pakistan's Border Policies and Security Dynamics along the Pakistan-Afghanistan Border, Journal of Borderlands Studies, 35(2), 211-226. DOI: 10.1080/08865655.2018.1545598 Polovnikov, V., Biletskyi, V., Tyshchuk, V., \& Overchenko, Y. (2020). Criminological profile of a perpetrator of a high treason. Amazonia Investiga, $9(28)$, https://doi.org/10.34069/AI/2020.28.04.21 Weisburd, D., Groff, E and Yang, S-M (2012) The Criminology of Place: Street Segments and Our Understanding of the Crime Problem. New York: Oxford University Press. DOI: 10.1093/acprof:oso/9780195369083.001.0001 